
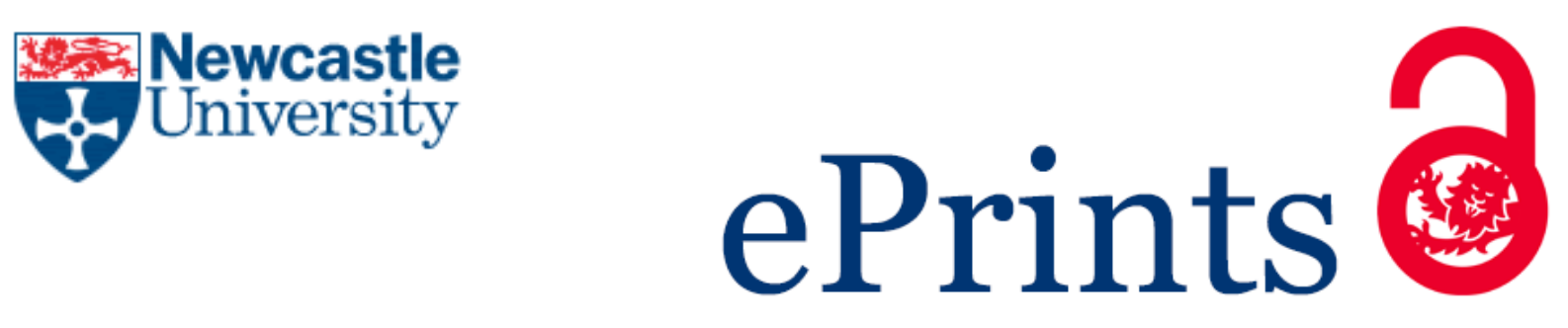

Tingay MRP, Rudolph ML, Manga M, Davies RJ, Wang CY.

Initiation of the Lusi mudflow disaster.

Nature Geoscience 2015, 8(7), 493-494.

\title{
Copyright:
}

This is the authors' manuscript of an article published in its final form by Nature Publishing Group, 2015.

The terms for reuse of the manuscript are available at:

http://www.nature.com/authors/policies/license.html

Link to published article:

http://dx.doi.org/10.1038/ngeo2472

Date deposited:

$06 / 10 / 2015$

Embargo release date:

29 December 2015 


\section{Initiation of the Lusi Mudflow Disaster}

2

3 M. R. P. Tingay ${ }^{1}$, M. L. Rudolph ${ }^{2}$, M. Manga ${ }^{3}$, R. J. Davies ${ }^{4}$, Chi-Yuen Wang $^{3}$

4

$5 \quad{ }^{1}$ Australian School of Petroleum, University of Adelaide, Adelaide, Australia

$6 \quad 2$ Department of Geology, Portland State University, Portland, OR, USA

$7 \quad{ }^{3}$ Department of Earth and Planetary Science, University of California, Berkeley,

8 CA, USA

$9{ }^{4}$ School of Civil Engineering and Geosciences, Newcastle University, Newcastle, 10 UK

11

12 The Lusi mudflow on Java is a unique disaster in which mud suddenly erupted in

13 an urban area. Nine years of continuous eruption has displaced 39700 people

14 and cost over US\$2.7 billion in damages and disaster management. Intense

15 debate has focused on whether the eruption was naturally triggered by the

16 Mw6.3 Yogyakarta earthquake (2 days prior, $260 \mathrm{~km}$ away) ${ }^{1,2}$ or was the result

17 of drilling operations in the nearby Banjar Panji-1 (BJP-1) well ${ }^{3,4}$. Arguments

18 surrounding the 'earthquake triggering' hypothesis are centered on whether the

19 Yogyakarta earthquake could trigger liquefaction of the Kalibeng clay formation

20 (900-1870m depth), the source of solids in the erupting mud ${ }^{1,2}$. Here we use

21 subsurface gas measurements from BJP-1 to show that there was no significant

22 change in gas release after the earthquake, demonstrating that liquefaction did

23 not occur. Moreover, comparison of subsurface and erupted gas compositions

24 indicates that the initial eruption expelled fluid from a deeper source than the

25 Kalibeng Clays. Taken together, these two observations provide key insight into 
26 the initial plumbing system of the Lusi mudflow and allow the earthquake-

27 triggering hypothesis to be directly tested.

Clay liquefaction is initiated by changes in effective stress (stress minus fluid pressure), and these same changes will also cause the widespread release of formation gases by dissolution (effective stress drop) or compaction-associated fluid expulsion (effective stress increase) $)^{1,2,5}$. Indeed, large gas releases are observed during mud volcano eruptions, and liquefaction at Lusi would have been immediately associated with extensive gas release ${ }^{2,6}$.

The BJP-1 borehole was located just $150 \mathrm{~m}$ from what became the main vent of the Lusi mud volcano and, being uncased from 1090 to 2833 m depth, was directly exposed to almost the entire thickness of the Kalibeng clays ${ }^{3,4,7}$ (Figure 1). A range of gas measurements were taken continuously during all drilling operations, starting from March 2006 up to the day of the Lusi mud eruption $(29 / 5 / 2006)^{7,8}$. Gas measurements obtained from the BJP-1 well provide a unique opportunity to determine baseline formation gas data prior to the

43 Yogyakarta earthquake and Lusi eruption, and to make a detailed examination of 44 the response of the Kalibeng clays immediately after the earthquake.

We use daily maximum gas measurements and continuous depth-based measurements ${ }^{9}$ to characterize the range of gas values observed in formations

49 maximum values observed in the 48 hours before, and 24 hours after, the 50 Yogyakarta earthquake ${ }^{7,8}$ (Supplementary Table 2). No increase in subsurface 
51 gases was measured in the 24 hours after the earthquake, which covers almost

52 the entire period between the earthquake and the major fluid influx ('kick') into

53 the BJP-1 wellbore7. Indeed, maximum gas readings after the earthquake are

54 noticeably lower than in the two previous days, but are within the normal range

55 of gas values recorded from the volcanic and volcaniclastic formation under the

56 clays, and particularly the calcareous volcaniclastic sequences below $2600 \mathrm{~m}$. The

57 post-earthquake gas readings from BJP-1 are significantly lower than typical

58 measurements in the Kalibeng clays, particularly with regards to heavier gases

$59\left(\mathrm{C}_{4}-\mathrm{C}_{5}\right)$; that are diagnostically high in this formation ${ }^{8}$. It is important to note that

60 increased gas levels would be expected regardless of whether the earthquake

61 had induced dilation (through gas exsolution) or compaction (higher pore

62 pressures causing increased fluid and gas flow into BJP-12 ${ }^{2,8}$. Any liquefaction or

63 remobilization would also cause wellbore instability in the Kalibeng formation

64 and clay cavings in the drilling mud, and neither were detected in the period

65 between the earthquake and the kick in BJP-14,7,8.

67 The gas data from BJP-1 also provide new evidence to identify the fluid source

68 driving the initial Lusi mud eruption, a critical difference between published

69 models for the initial eruption $1,2,3,4,6,7,10$. Each formation encountered by BJP-1

70 has a distinct range of gas readings that can be used to 'fingerprint' the formation

71 from which fluids emanated (Supplementary Table 2). Of particular relevance is

72 the observation of minor $\mathrm{H}_{2} \mathrm{~S}$ from BJP-1 several hours before the earthquake,

73 just 20 meters from the bottom of the BJP- 1 well ${ }^{8} . \mathrm{H}_{2} \mathrm{~S}$ was then observed coming

74 from BJP-1 during the drilling kick, and also from Lusi in the initial days of the

75 eruption ${ }^{4,7,8,10} . \mathrm{H}_{2} \mathrm{~S}$ was not observed at any time while drilling the Kalibeng 
clays, despite direct gas measurements from $\sim 60 \mathrm{~m}^{3}$ of Kalibeng cuttings ${ }^{8}$. The only known source of $\mathrm{H}_{2} \mathrm{~S}$ in the East Java Basin is from Tertiary carbonates ${ }^{8,10}$, such as the Miocene carbonates targeted by BJP-1, although $\mathrm{H}_{2} \mathrm{~S}$ could alternatively have a volcanic or hydrothermal origin ${ }^{6}$. Whilst it is not certain whether the BJP-1 well penetrated the Miocene carbonates, drilling reports state the carbonates were possibly penetrated at $2831 \mathrm{~m}^{7}$, and it is generally accepted that the bottom of BJP-1 was within, or in communication with, these carbonates $3,4,7,8,10$. The observation of $\mathrm{H}_{2} \mathrm{~S}$ near the base of BJP-1 prior to the earthquake thus provides compelling evidence that an initial source of fluids for the Lusi eruption was significantly deeper than the Kalibeng clays.

\section{The presence of a deep fluid source for the Lusi mudflow has been previously} demonstrated from the analysis of erupted gas samples (collected months to years after the eruption began $)^{6}$. This observation led to the hypothesis that a natural hydrothermal system existed at the Lusi site, and that deep fluids had 'pre-charged' the Kalibeng clays, priming the clays for remobilization by the Yogyakarta earthquake ${ }^{6}$. However, the observation of deep $\mathrm{H}_{2} \mathrm{~S}$ at the base of BJP-1, and absence of any measured $\mathrm{H}_{2} \mathrm{~S}$ in the Kalibeng clays, suggests that there was no pre-eruption fluid communication between the Kalibeng clays and the Miocene carbonates (or deeper formations). Whilst it is possible that Lusi had an initial hydrothermal influence, the gas data herein indicates that this must be a deep system, within the Miocene carbonates or deeper. source of erupting fluids to be the Kalibeng clays ${ }^{1,2}$, whilst published models for 
101 Lusi being a natural hydrothermal system involve pre-eruption migration of 102 deep fluids into the Kalibeng clays ${ }^{1,6}$. The absence of any evidence of liquefaction

103 or deep 'pre-charging' of the Kalibeng clays thus directly contradicts natural

104 triggering models for the Lusi disaster. The gas data indicate that initial driving

105 fluids were from the Miocene carbonates (or deeper), and that a fluid pathway

106 through 940 meters of low permeability volcanics/volcaniclastics ${ }^{8}$ suddenly

107 developed immediately prior to the Lusi eruption. This matches with the drilling

108 trigger hypothesis $3,4,7,10$, which proposes a deep initial source of fluids for the

109 Lusi mud flow, and that these flowed into the Kalibeng clays via the open BJP-1

110 wellbore.

112 In summary, measurements demonstrate that no gas flux increase occurred at 113 any time in the 24 hours following the Yogyakarta earthquake. These results 114 reveal that the earthquake did not trigger Kalibeng clay liquefaction at the Lusi

115 location. Furthermore, gas data indicate that initial Lusi fluids were sourced from

116 Miocene carbonates ${ }^{8,10}$ or a deep hydrothermal system ${ }^{6}$, and that there was no

117 pre-eruption fluid communication between the Kalibeng clays and these deeper

118 formations. Hence, the gas data from BJP-1 provides compelling evidence against

119 published earthquake-triggering ${ }^{1,2}$ and natural hydrothermal ${ }^{6}$ models for the

120 triggering of the Lusi mudflow. In contrast, the data support models that invoke

121 an influx of deep fluids into the well 3,4 , and hence that drilling operations

122 initiated the eruption.

123

\section{References}

125 1. Mazzini, A. et al. Strike-slip faulting as a trigger mechanism for overpressure 
126 release through piercement structures. Implications for the Lusi mud volcano,

127 Indonesia. Mar. Petrol. Geol. 26, 1751_1765 (2009).

128 2. Lupi, M., Saenger, E. H., Fuchs, F. \& Miller, S. A. Lusi mud eruption triggered by

129 geometric focusing of seismic waves. Nature Geosci. 6, 642-646 (2013).

130 3. Tingay, M., Heidbach, O., Davies, R. \& Swarbrick, R. Triggering of the

131 Lusi mud eruption: Earthquake versus drilling initiation. Geology 36,

132 639-642 (2008).

133 4. Davies, R. J. et al. The East Java mud volcano (2006 to present): An earthquake

134 or drilling trigger? Earth Planet. Sci. Lett. 272, 627-638 (2008).

135 5. Rydelek, P. A., \& Tuttle, M. Explosive craters and soil liquefaction. Nature 427,

136 115-116 (2004).

137 6. Mazzini, A., Etiope, G. \& Svensen, H. A new hydrothermal scenario for the 2006

138 Lusi eruption, Indonesia. Insights from gas geochemistry. Earth Planet. Sci. Lett.

$139317,305-318$ (2012).

140 7. Sawolo, N., Sutriono, E., Istadi, B. P. \& Darmoyo, A. B. The Lusi mud volcano

141 triggering controversy: Was it caused by drilling? Mar. Petrol. Geol. 26,

142 1766-1784 (2009).

143 8. Tingay, M. Initial pore pressures under the Lusi mud volcano, Indonesia.

144 Interpretation 3, SE33-SE49 (2015).

145 9. McPhater, D. \& MacTiernan, B. Well-site Geologist's Handbook. PennWell Books 146 (1983).

147 10. Davies, R. J., Swarbrick, R. E., Evans, R. J., \& Huuse, M. Birth of a mud volcano:

148 East Java, 29 May 2006. GSA Today 17, 4-9 (2007). 
151 B. Istadi is appreciated for providing data access. We thank D. Dewhurst and W.

152 Evans for comments. The US-based authors are supported by the National

153 Science Foundation.

154

155 Author contributions

156 M.T. collected the data, conducted the study and jointly wrote the manuscript

157 with M.R. and M.M. M.R. coordinated the study and conducted gas analysis. M.M.

158 conducted gas and seismological analysis. R.D. collected data. C.Y.W. conducted

159 seismological analysis.

160

161 Additional information

162 Supplementary information is available in the online version of the paper.

163 Reprints and permissions information is available online at

164 www.nature.com/reprints. Correspondence and requests for materials should

165 be addressed to M.T.

166

167 Competing financial interests

168 The authors declare no competing financial interests. 


\section{Figure Captions}

171

172 FIGURE 1: Stratigraphy, design of the BJP-1 borehole and measured gases

173 amounts encountered by the BJP-1 well7,8. Total gas is the percent of gas, by

174 volume, extracted from drilling mud returned from a specific depth ${ }^{9}$. Gases data

175 is the concentrations of individual gases from individual depths, as measured by

176 gas chromatography9. Gas amounts are significantly higher in the Kalibeng clays,

177 particularly for heavier gases $\left(\mathrm{C}_{4}-\mathrm{C}_{5}\right)$, than in the volcanics and volcaniclastics

178 (particularly the lowermost calcareous volcaniclastics below 2600m depth;

179 Supplementary Table 1). Liquefaction of the Kalibeng clays would be associated

180 with extensive gas release ${ }^{2}$. However, no increase in gas flux is observed in the

18124 hours after the Yogyakarta earthquake, and gas readings are within the

182 normal range of those observed when drilling the deep calcareous volcaniclastic

183 sequences (Supplementary Table 2).

184 


\section{BJP-1 Lithology,}

Formations and Casing

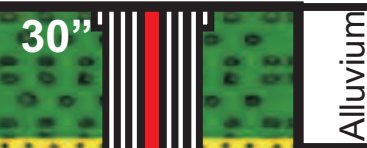

$\because x^{3}$

16

$13^{3}$,

8

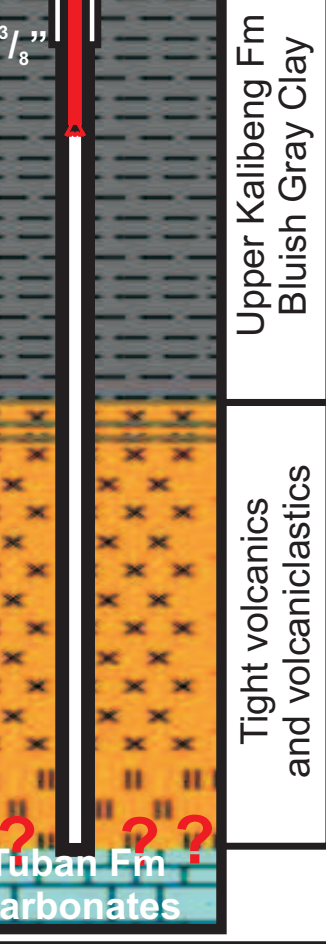

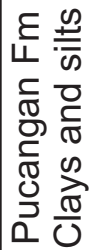

Total Gas (\%)

s)

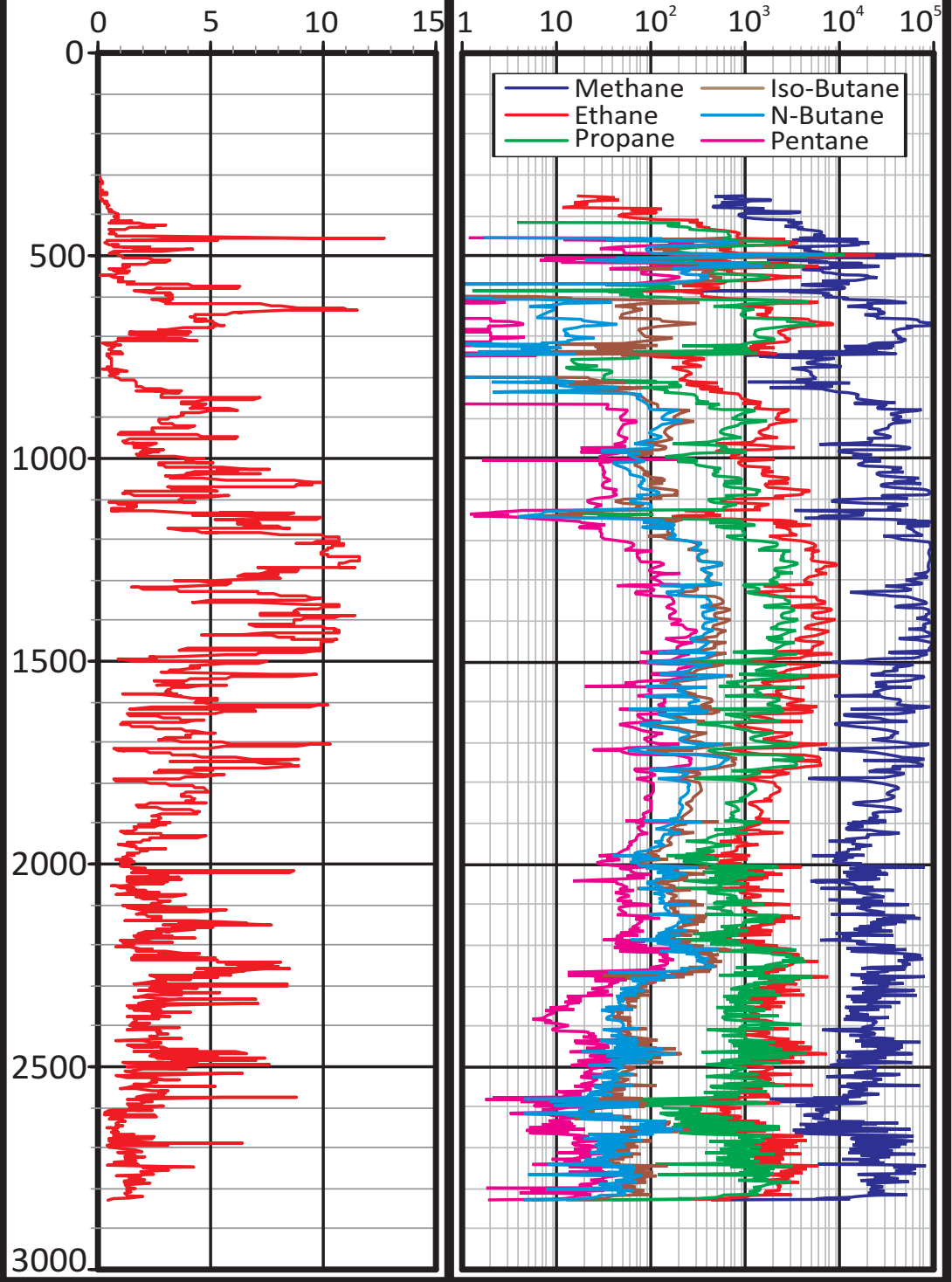

Gases (ppm)

$151110 \quad 10^{2} \quad \begin{array}{llll}10^{3} & 10^{4} & 10^{5}\end{array}$ 


\title{
Initiation of the Lusi mudflow disaster
}

\author{
M. Tingay, M. Rudolph, M. Manga, R. Davies, Chi-Yuen Wang
}

SUPPLEMENTARY TABLE 1: Gas measurements for key formations under the Lusi mud volcano ${ }^{7,8}$. Average values for each formation are stated, with typical background gas ranges provided in brackets. Gas measurements in the volcanic and volcaniclastic sequences are generally less than half of those observed in the Kalibeng clays, and the Kalibeng clays are particularly higher in heavier fractions $\left(\mathrm{C}_{4}\right.$ and $\left.\mathrm{C}_{5}\right)$. ${ }^{*} \mathrm{H}_{2} \mathrm{~S}$ readings observed at 2:00am on the 27/5/2006 and 20m from the bottom of Banjar Panji-1 (BJP-1) are interpreted to be from the Miocene carbonates (or deeper source) that diffused into the lowermost volcaniclastic sequences ${ }^{8} . \mathrm{n} / \mathrm{a}$ indicates data not available.

\begin{tabular}{|c|c|c|c|c|c|c|c|c|}
\hline Formation & $\begin{array}{c}\text { Total } \\
\text { Gas (\%) }\end{array}$ & $\begin{array}{c}\mathrm{C}_{1} \\
(\mathrm{ppm})\end{array}$ & $\begin{array}{c}\mathrm{C}_{2} \\
(\mathrm{ppm})\end{array}$ & $\begin{array}{c}\mathrm{C}_{3} \\
(\mathrm{ppm})\end{array}$ & $\begin{array}{c}\mathrm{iC}_{4} \\
(\mathrm{ppm})\end{array}$ & $\begin{array}{c}\mathrm{nC}_{4} \\
(\mathrm{ppm})\end{array}$ & $\begin{array}{c}\mathrm{C}_{5} \\
(\mathrm{ppm})\end{array}$ & $\begin{array}{c}\mathrm{H}_{2} \mathrm{~S} \\
(\mathrm{ppm})\end{array}$ \\
\hline $\begin{array}{l}\text { Kalibeng clays } \\
(900-1870 \mathrm{~m})\end{array}$ & $\begin{array}{c}5.5 \\
(2-12)\end{array}$ & $\begin{array}{c}49997 \\
(20000- \\
110000)\end{array}$ & $\begin{array}{c}3300 \\
(2000- \\
14000)\end{array}$ & $\begin{array}{c}1497 \\
(1000-3000)\end{array}$ & $\begin{array}{c}304 \\
(200-1000)\end{array}$ & $\begin{array}{c}242 \\
(200-1000)\end{array}$ & $\begin{array}{c}105 \\
(80-200)\end{array}$ & 0 \\
\hline $\begin{array}{c}\text { Volcanics/ } \\
\text { volcaniclastics } \\
(1870-2600 \mathrm{~m})\end{array}$ & $\begin{array}{c}2.7 \\
(1-6)\end{array}$ & $\begin{array}{c}24116 \\
(10000- \\
80000)\end{array}$ & $\begin{array}{l}1698 \\
(500- \\
5000)\end{array}$ & $\begin{array}{c}1053 \\
(300-2500)\end{array}$ & $\begin{array}{c}158 \\
(70-350)\end{array}$ & $\begin{array}{c}121 \\
(50-300)\end{array}$ & $\begin{array}{c}51 \\
(10-80)\end{array}$ & 0 \\
\hline $\begin{array}{c}\text { Calcareous } \\
\text { Volcaniclastics } \\
(2600-2833 \mathrm{~m})\end{array}$ & $\begin{array}{c}1.7 \\
(0.5-2)\end{array}$ & $\begin{array}{l}23576 \\
(5000- \\
60000)\end{array}$ & $\begin{array}{c}1712 \\
(1000- \\
3000)\end{array}$ & $\begin{array}{c}913 \\
(190-1800)\end{array}$ & $\begin{array}{c}60 \\
(20-90)\end{array}$ & $\begin{array}{c}48 \\
(10-80)\end{array}$ & $\begin{array}{c}17 \\
(5-30)\end{array}$ & $0^{*}$ \\
\hline $\begin{array}{l}\text { Carbonates } \\
(\geq 2833 \mathrm{~m})\end{array}$ & $\mathrm{n} / \mathrm{a}$ & $\mathrm{n} / \mathrm{a}$ & $\mathrm{n} / \mathrm{a}$ & $\mathrm{n} / \mathrm{a}$ & $\mathrm{n} / \mathrm{a}$ & $\mathrm{n} / \mathrm{a}$ & $\mathrm{n} / \mathrm{a}$ & Common \\
\hline
\end{tabular}

\section{SUPPLEMENTARY TABLE 2: Maximum gas measurements from BJP-1 before and after the}

Yogyakarta earthquake ( 6:00am 26/5/2006; separated by thick lines $)^{7}$. n/a indicates data not available.

\begin{tabular}{|c|c|c|c|c|c|c|c|c|c|c|}
\hline $\begin{array}{c}\text { Date (May } \\
\text { 2006) }\end{array}$ & $\begin{array}{c}\text { Total } \\
\text { Gas (\%) }\end{array}$ & $\begin{array}{c}\mathrm{C}_{1} \\
(\mathrm{ppm})\end{array}$ & $\begin{array}{c}\mathrm{C}_{2} \\
(\mathrm{ppm})\end{array}$ & $\begin{array}{c}\mathrm{C}_{3} \\
(\mathrm{ppm})\end{array}$ & $\begin{array}{c}\mathrm{iC}_{4} \\
(\mathrm{ppm})\end{array}$ & $\begin{array}{c}\mathrm{nC}_{4} \\
(\mathrm{ppm})\end{array}$ & $\begin{array}{c}\mathrm{iC}_{5} \\
(\mathrm{ppm})\end{array}$ & $\begin{array}{c}\mathrm{nC}_{5} \\
(\mathrm{ppm})\end{array}$ & $\begin{array}{c}\mathrm{CO}_{2} \\
(\mathrm{ppm})\end{array}$ & $\begin{array}{c}\mathrm{H}_{2} \mathrm{~S} \\
(\mathrm{ppm})\end{array}$ \\
\hline $\begin{array}{c}6 \text { am 25/5 - } \\
6 \text { am 26/5 }\end{array}$ & 6.5 & 57816 & 4212 & 1753 & 65 & 60 & 24 & 13 & 868 & 0 \\
\hline $\begin{array}{c}6 \text { am } 26 / 5- \\
6 \text { am } 27 / 5\end{array}$ & 8.3 & 75024 & 4949 & 2034 & 91 & 74 & 34 & 22 & 593 & 25 \\
\hline $\begin{array}{c}\text { 6am 27/5 - } \\
6 \text { am 28/5 }\end{array}$ & 1.6 & 14445 & 685 & 197 & 20 & 11 & 6 & 5 & 354 & 0 \\
\hline $\begin{array}{c}\text { Kick (730am } \\
28 / 5)\end{array}$ & 20 & $\mathrm{n} / \mathrm{a}$ & $\mathrm{n} / \mathrm{a}$ & $\mathrm{n} / \mathrm{a}$ & $\mathrm{n} / \mathrm{a}$ & $\mathrm{n} / \mathrm{a}$ & $\mathrm{n} / \mathrm{a}$ & $\mathrm{n} / \mathrm{a}$ & $\mathrm{n} / \mathrm{a}$ & 500 \\
\hline
\end{tabular}




\section{Methodology for Drilling Mud Gas Analysis}

Gas amounts contained within drilling mud are routinely and continuously measured during hydrocarbon drilling operations for safety reasons (e.g. detection of potentially harmful or explosive gases, such as $\mathrm{H}_{2} \mathrm{~S}$ and methane) and to provide information on pore fluid content (e.g. hydrocarbons $)^{9}$. Drilling mud is continuously circulated through the borehole whilst drilling. Mud is first pumped down through the drill string to the bit, and back to the surface via the annular space between the string and wellbore wall. As drilling mud flows up the wellbore annulus, subsurface gases flow into the mud through direct diffusion out of formations exposed by the wellbore, and through release of gasses trapped within drilled material ('cuttings' $)^{9}$. The drilling mud passes through gas separation equipment at the surface, and chromatography is used to precisely measure the amounts of hydrocarbon and other gases ${ }^{9}$. Additional gas sensors are also deployed around the drill rig (such as at the wellhead and shale shakers) for safety reasons, and to provide supporting data for gas analysis ${ }^{9}$.

The amount of formation gas observed in drilling mud is a function of the rock being drilled (hydrocarbon content, porosity, permeability), the rate of penetration (faster drilling yields more drilled material and more gases in the mud), mud circulation rate (higher rate provides less time for gas to diffuse into mud), differential pressure (mud pressure minus pore pressure; higher differential pressure results in less gas flow into wellbore), mud type (formation gas is highly soluble in oil-based mud, as used in BJP-1) and hole diameter (higher gas readings due to larger wellbore surface area) ${ }^{9}$. Rock type, rate of penetration and mud circulation rate are the main controls on mud gas chemistry in BJP-1, as other parameters were all approximately constant in the open wellbore ${ }^{7,8}$, although the Kalibeng clay displays zones of significant borehole enlargement compared to the underlying volcanic and volcaniclastic sequences ${ }^{8}$. In particular, mud pressure in BJP-1 was approximately equal to the pore fluid pressure during drilling of the entire open wellbore section ${ }^{7}$, providing ideal conditions for formation fluids to enter the borehole (Mouchet and Mitchel, 1989).

Mud gas readings are higher in the Kalibeng clays than in the volcanic/volcaniclastic sequences due to its high porosity (35-50\%) and organic material content ${ }^{1,8}$, which also allowed for higher rates of penetration ${ }^{7,8}$. Comparison of daily gas readings must also consider that only $\sim 7$ hours of drilling operations took place after the earthquake ${ }^{4,7,8}$. Drilling operations were halted following total mud losses (of between 20670-73458 liters, or $10-36 \%$ of total hole volume ${ }^{7,8}$ ), after which the well was refilled with drilling mud, circulated slowly for several hours and the process of removing the drill string from the hole was initiated ${ }^{7,8}$. The cessation of drilling operations may have resulted in the observed lower maximum gas readings in the 24 
hours after the earthquake because less drilled rock material was collected, and thus no further cuttings gas would be present after the losses at final depth. However, this is significantly offset by the lower average circulation rate while pulling out of hole, in which the drilling mud was allowed to sit static and absorb formation gases for extended periods ${ }^{7,8}$. Drilling mud was circulated 8 times whilst pulling out of the hole, with the well left static for intervening periods of between 24 to 98 minutes (with an average of 57 minutes) ${ }^{7}$. The rapid movement of the drill bit and drill collars whilst pulling out of the hole may also cause localized suction pressures inside the wellbore ('swabbing'), which may have pulled more formation fluid and gas into the well ${ }^{4,10}$. It is uncertain whether swabbing occurred in BJP-1. Swabbing is often associated with increased force required to pull the drill string out of the hole, and Sawolo et al. (2009) cite "no apparent drag" as evidence that swabbing did not occur ${ }^{6}$, but this is contradicted by original drilling reports that state "pipe worked from 2652-2591m" and "overpull increasing", and thus may indicate swabbing. Overall, the reduced average circulation rates and possible swabbing effects are expected to offset any reduced gas levels from the absence of drilled cuttings after the total losses. Furthermore, none of the observed drilling parameters or conditions would mask or obscure liquefaction-induced gas release into the wellbore. Indeed, the conditions in BJP-1 were extremely well suited for detecting any gas release from the Kalibeng clays following the earthquake, as these effects would be expected to be at least as large, and likely much greater than, the gas measurements observed during drilling of the clays.

It is important to note that earthquake-triggered liquefaction of the Kalibeng clay would have been expected to result in other observable effects in BJP-1, in addition to increased gas amounts. Liquefaction or remobilization of the clays would cause clay to move into the wellbore, which would result in clay cavings being observed at the surface and may also cause the drill string to be difficult to pull out of the hole through the clays. However, no observations of clay material were reported following the earthquake, and the only wellbore instability observed was in the volcanics and volcaniclastics in the bottom 300 meters of the well (possibly due to swabbing), and then immediately following the major kick (26 hours after the earthquake $)^{7,8}$.

An effective stress drop due to the earthquake ${ }^{2}$, or even direct fault reactivation ${ }^{1,7}$, might be associated with loss of drill mud into the formation. Indeed, it has been claimed that 3180 liters of mud were lost into the formation approximately seven minutes after the Yogyakarta earthquake (6:02am) $)^{1,7}$. These minor losses could correlate with the arrival of earthquake seismic waves at the Lusi location, and thus may be an indication of an effect of the earthquake on the BJP-1 well ${ }^{1,2,7}$. However, there is significant uncertainty over the reported time of these $\operatorname{losses}^{8}$, with the original data ${ }^{7}$ alternatively indicating that these losses may have occurred at $\sim 5: 00 \mathrm{am}^{8}$, and clearly identifying that the losses occurred when drilling at 2827 meters depth, which corresponds to the drilling depth at $\sim 05: 00 \mathrm{am}^{7}$. Thus, there is strong evidence that these minor losses 
in BJP-1 occurred approximately one hour before the earthquake ${ }^{8}$. Furthermore, it has been noted that the total losses at the bottom of the well occurred "less than two hours after two major aftershocks", and that "the proximity of the times suggest that the earthquake had an impact down hole in the well"? . Yet, it is highly uncertain whether there is any direct correlation between the three large aftershocks following the main Yogyakarta earthquake (Mw4.4 at 8:07am, Mw4.8 at 10:10am and Mw4.6 at 11:22am) and the total losses (at 12:50pm) that occurred between 90 and 280 minutes afterwards ${ }^{7}$, particularly given their significantly smaller size (compared to the main shock) and the large distance ( $260 \mathrm{~km})$ to the Lusi location $^{3,4}$ (Manga, 2007). Finally, it is interesting to note that, whilst there are no reliable indications of clay liquefaction in the 24 hours following the Yogyakarta earthquake, there are numerous indications of Kalibeng clay activity associated with the major drilling kick in BJP-1. Observations during and after the kick include high gas flows (20\% gas), wellbore instability (bit stuck, drill string packed-off), significant volumes of formation material migrating into the casing, pore fluid influxes, drilling mud losses and evidence of direct communication between BJP-1 and the Lusi main vent ${ }^{4,7,810}$. Hence, there is extensive evidence from the BJP-1 well that liquefaction, remobilization or entrainment of the Kalibeng clay occurred prior to, and during the first days of, the Lusi eruption, but these appear to be in response to the drilling kick in BJP-1.

\section{Additional References}

Manga, M. Did an earthquake trigger the May 2006 eruption of the Lusi mud volcano? Eos 88, 201 (2007). Mouchet, J. P. \& Mitchell, A. Abnormal pressures while drilling. Elf Aquitaine (1989). 